\title{
THE EFFECT OF OMEGA-3 POLYUNSATURATED FATTY ACIDS ON AMBULATORY BLOOD PRESSURE MONITORING PARAMETERS IN PATIENTS WITH TYPE 2 DIABETES MELLITUS AND CARDIOVASCULAR AUTONOMIC NEUROPATHY
}

\author{
(c) Victoria A. Serhiyenko', Boris N. Mankovsky², Ludmila M. Serhiyenko', Alexandr A. Serhiyenko ${ }^{1}$
}

'Danylo Halitsky National Medical University, Lviv, Ukraine

${ }^{2}$ P.L. Shupik National Medical Academy of Postgraduate Education, Kyiv, Ukraine

BACKGROUND: Cardiovascular autonomic neuropathy (CAN) in type 2 diabetes mellitus (T2DM), which is characterized by lesion of nerve fibers in parasympathetic and sympathetic nervous system is one of the leading causes of heart arrhythmias and an independent risk factor for cardiovascular mortality in patients with T2DM. Therefore, the problem of effective treatment of CAN is particularly relevant.

AIMS: To analyze the effect of long-chain polyunsaturated fatty acids ( $\omega$-3 PUFAs) on ambulatory blood pressure monitoring parameters in patients with T2DM and CAN.

MATERIALS AND METHODS: 36 patients with T2DM and confirmed CAN were divided into two groups. First group received hypoglycemic therapy ( $n=15$, control) for three months; patients in group $2(n=21)$ in addition were administered 1 capsule/q.d. of $\omega$-3 PUFAs for three month.

RESULTS: Treatment with $\omega$-3 PUFAs led to significant decrease of the diastolic blood pressure (DBP) ( $p<0,01)$, diastolic blood pressure load $(p<0,05)$, time index of DBP $(p<0,05)$ during the day; DBP $(p<0,05)$, diastolic blood pressure load $(p<0,05)$, time index of DBP $(p<0,05)$, SD DBP $(p<0,01)$ during the night (compared to the control group).

CONCLUSIONS: The study showed that prescription of $\omega-3$ PUFAs for three month was effective in decreasing diastolic blood pressure and its parameters among patients with T2DM and CAN.

KEYWORDS: diabetic cardiovascular autonomic neuropathy; polyunsaturated fatty acids; ambulatory blood pressure monitoring

\section{ВЛИЯНИЕ ОМЕГА-З ПОЛИНЕНАСЫЩЕННЫХ ЖИРНЫХ КИСЛОТ НА ПАРАМЕТРЫ АМБУЛАТОРНОГО МОНИТОРИНГА АРТЕРИАЛЬНОГО ДАВЛЕНИЯ У ПАЦИЕНТОВ С САХАРНЫМ ДИАБЕТОМ 2 ТИПА И АВТОНОМНОЙ НЕВРОПАТИЕЙ СЕРДЦА}

\author{
(с) В.А. Сергиенко', Б.Н. Маньковский², Л.М. Сергиенко', А.А. Сергиенко
}

1Львовский национальный медицинский университет им. Данила Галицкого, Львов, Украина

${ }^{2}$ Национальная медицинская академия последипломного образования им. П.Л. Шупика, Киев, Украина

ОБОСНОВАНИЕ. Диабетическая автономная невропатия сердца (ДАНС) при сахарном диабете 2 типа (СД2) характеризуется поражением нервных волокон парасимпатической и симпатической нервной системы, является одной из ведущих причин сердечных аритмий и независимым фактором риска сердечно-сосудистой смертности у пациентов с СД2. Поэтому проблема эффективного лечения ДАНС особенно актуальна.

ЦЕЛЬ. Проанализировать влияние длинноцепочечных полиненасыщенных жирных кислот ( $\omega$-3 ПНЖК) на параметры амбулаторного мониторинга артериального давления у пациентов с СД2 и ДАНС.

МЕТОДЫ. 36 пациентов с СД2 и подтвержденной ДАНС были разделены на 2 группы. Первая группа получала гипогликемическую терапию ( $\mathrm{n}=15$, контроль) в течение 3 мес; пациентам второй группы ( $\mathrm{n}=21)$ дополнительно назначали 1 капсулу/сут препарата $\omega-3$ ПНЖК в течение 3 мес.

РЕЗУЛЬТАТЫ. Использование $\omega$-3 ПНЖК сопровождалось значительным снижением диастолического артериального давления (ДАД) ( $<<0,01)$, индекса площади гипертонии ДАД ( $<<0,05)$, индекса времени гипертонии ДАД (р<0,05) В течение дня; ДАД ( $<<0,05)$, индекса площади гипертонии ДАД ( $<<0,05)$, индекса времени гипертонии ДАД ( $<<0,05)$, стандартного отклонения ДАД ( $<<0,01)]$ в ночные часы (по сравнению с контрольной группой).

ЗАКЛЮЧЕНИЕ. Полученные результаты свидетельствуют, что назначение $\omega$-3 ПНЖК на протяжении 3 мес эффективно влияет на снижение параметров ДАД у больных СД2 и ДАНС. 
КЛЮЧЕВЫЕ СЛОВА: диабетическая кардиоваскулярная автономная нейропатия; полиненасыщенные жирные кислоты; мониторинг артериального давления

The majority of patients with type 2 diabetes mellitus (T2DM) are diagnosed with coronary heart disease (CHD) due to coronary artery atherosclerosis. Metabolic alterations in the myocardium are combined with early coronary atherosclerosis. All these changes in the heart occur over a prolonged duration of DM among middle aged and elderly patients [coronary vessels affection, myocardium changes, diabetic cardiovascular autonomic neuropathy (CAN) and sclerotic arterial disease] are associated with the term "diabetic heart" [1]. CAN in T2DM is one of the leading causes of heart arrhythmias and an independent risk factor for cardiovascular mortality in patients with $\operatorname{T2DM}[2,3]$. Therefore, the problem of effective treatment of CAN is particularly relevant. Pathogenetic treatment of CANincludes balanced diet and physical activity; optimizing of glycemic control; treatment of dyslipoproteinemia (DLP); correction of metabolic abnormalities in myocardium; prevention and treatment of thrombosis; use of aldose reductase inhibitors; $\gamma$-linolenic acid, acetyl-L-carnitine, antioxidants, use of $\omega$-3 and $\omega-6$ polyunsaturated fatty acids ( $\omega-3$ and $\omega-6$ PUFAs), vasodilators, fat-soluble vitamin B1 and others [4-6].

Arterial stiffening is caused by the loss of vascular elasticity due to factors such as aging and atherosclerosis. It depends on the structural properties of the arterial wall that affect the manner in which pressure, blood flow, and arterial diameter change within each heartbeat. Arterial stiffness depends on the balance between extracellular proteins and their distribution along the arterial wall. An increased arterial stiffness is associated with hypertension (HT) and it is an independent direct predictor of cardiovascular events [7,8]. Arterial stiffening characterizes aging and several diseases related to increased cardiovascular risk such as the metabolic syndrome, T2DM, HT, obesity and smoking. Pulse wave velocity (PWV), a marker of arterial stiffness, can be non-invasively estimated by the evaluation of waveforms in the carotid and femoral or radial artery using certain devices [9].

Meta-analysis of randomized and controlled human clinical trials provides compelling evidence that supplementation with long-chain omega-3 PUFAs offers a scientifically supported means of reducing blood pressure (BP) $[10,11]$. However, research regarding the features of $\omega-3$ and $\omega-6$ PUFAs in diabetic patients without diagnosed CHD are scarce, and the results do not confirm their effectiveness [12].

\section{AIM}

The aim of this study was to examine the effect of longchain $\omega-3$ PUFAs supplementation on ambulatory blood pressure monitoring (ABPM) parameters in patients with type 2 diabetes mellitus and cardiovascular autonomic neuropathy.

\section{METHODS}

\section{Study design}

This was open-label comparative controlled randomized study.

\section{Inclusion criteria}

Study inclusion criteria: age: 45-60 years old; T2DM with optimal or suboptimal glycemic control; T2DM patients with confirmed CAN; clinical stages of diabetic polyneuropathy; BMI within $20-30 \mathrm{~kg} / \mathrm{m}^{2}$; consent to observethe dietary regime with the limited use of foods containing saturated fatty acids during the study; consent to maintain appropriate physical activity. The examination excluded persons with uncontrolled DM, ketosis, peripheral vascular diseases, ischemic form of diabetic foot, distal neuropathy caused by other reasons than diabetes (neurological disease, chronic alcoholism, pharmalogical agents), neoplasms, hypothyroidism, history of acute pancreatitis, affected activity of lipoprotein lipase and/or DLP type III, women during pregnancy and lactation, patients with T1DM, hypersensitivity to the components of the medicinal product. Treatment with antidepressants, anticonvulsants, opiates, capsaicin, neuroleptic agents, cytostatic agents, B group vitamins, benfotiamine, $\gamma$-linoleic acid, aldose reductase inhibitors, isotretinoin (accutane), warfarin, antioxidants (including a-lipoic acid medications), $\omega-3$ PUFAs for six months prior to the inclusion in the study was also exclusion criteria. Patients suffering from severe diseases of the heart, lungs, liver, pancreas and intestines were also excluded from the study.

\section{Research facilities}

All patients were residents of the city of Lviv observed by endocrinologist at the department of Endocrinology of the Danylo Halitsky Lviv National Medical University based on Lviv Regional State Clinical Treatment and Diagnostical Endocrinological Center. On the basis of these institutions patients were examined and treated.

\section{Research duration}

The study has been conducted for 2 years (2015-2017 years). Each patient examined before the beginning of the study did not take $\omega-3$ PUFAs and was on stable regime of hypoglycemic and antihypertensive treatment for 6 month. After CAN diagnosing $\omega-3$ PUFAs was prescribed to patients from the treatment group according to the study design. The treatment of the control group was unchanged. The duration of the treatment period was 3 months. To determine the metabolic and hypotensive effects of the treatment the glycemic, lipids parameters and ABPM were performed initially and after the end of treatment.

\section{Medical procedure description}

Examination plan included determination of glucose, glycated hemoglobin $\mathrm{A} 1 \mathrm{c}\left(\mathrm{HbA}_{1 \mathrm{c}}\right)$, lipids in the blood, Electrocardiography (ECG), five cardiovascular autonomic reflex tests (CARTs), Holter-ECG and ABPM. All patients underwent screening for CAN that included CARTs, in addition time-domain and frequency-domain heart rate variability tests were performed $[4,6]$. The severity of autonomous neuropathy was determined on the condition that all five tests were performed. The results were considered according to scores obtained in individual tests. Physiological values were evaluated as "0" scores, borderline values - as "0.5" scores, pathological values - as "1" score. 
The scores were summed up and the severity of autonomic dysfunction was evaluated.

The standard hypoglycemic treatment of DM included dietary regime, appropriate physical activity and oral antihyperglycemic drugs. The therapy of the control group lead unchanged during the treatment period. To patients from treatment group 1 capsule/q.d. of the $\omega-3$ PUFAs in addition was prescribed for three months. The capsule contains $1 \mathrm{~g}$, including $90 \% \omega-3$ PUFAs, mainly eicosapentaenoic (EPA) and docosahexaenoic acids (DHA).

\section{Methods for registration of outcomes}

The concentration of glucose in the blood was determined by the glucose oxidase method while $\mathrm{HbA}_{1 \mathrm{c}}$ was assessed using a highly sensitive method of ionexchange liquid chromatography with D-10 analyzer and BIO-RAD reagents (USA). Lipid content was determined using HUMAN (Germany) reagents at the semi-automatic analyzer Humalyzer 2000. ECG results were analyzed using a 12-channel electrocardiograph "UCARD-200" (UTAS, Ukraine) and Holter-ECG [ECG "The EC-3H" (Labtech, Hungary)]. In order to evaluate the BP profile and artery stiffness parameters during the day and night ABPM using the device TensioMedTM Arteriograph [monitor BP "ABPM04" ("Meditech," Hungary) was performed. We investigated the following parameters: average systolic BP (SBP), diastolic $B P(D B P)$, pulse $B P$, heart rate $(H R)$ during the day, active and passive periods, hourly rates; maximum and minimum values of $\mathrm{BP}$ and $\mathrm{HR}$ at different times of day; BP indices; variability (SD) of SBP, DBP; diurnal index (DI) of SBP and DBP; indicators of "load pressure" [8, 13].

\section{Primary study outcome}

The antihypertensive effect of $\omega-3$ PUFAs, especially significant decrease of the DBP parameters (including load, time index and variability) during the day and night after 3 months of treatment.
Additional study outcomes

Metabolic efficacy of treatment was assessed by a reliable decrease in triglycerides (TG) and increase of high density lipoprotein cholesterol (HDL-C) after 3 months of $\omega$-3 PUFAs prescription.

\section{Ethical review}

The work was done according to the principles of the Declaration of Helsinki (2004) and was approved by an Ethics Committee of the Danylo Halytsky Lviv Medical University, protocol № 2 from 18 February 2013. All subjects signed an informed consent prior to their inclusion in the study. The research performed corresponded to the generally accepted norms of morality and observance of the rights, interests and personal dignity of the persons participating in the study.

\section{Statistical analysis}

To compare repeated measurements (before and after treatment) the Wilcoxon signed-rank test was used. A comparison of the obtained data in the two groups was carried out using the nonparametric Mann-Whitney test; median (Me) and interquartile range (Q25-Q75) were used for their description. The sample size was determined to allow us to detect differences before and after treatment between the groups with an effect size of 0.8 or more (power 0.8 , alpha<0.05). Statistical significance was set at $p<0.05$. All tests were performed using the ANOVA (MicroCal Origin v. 8.0) software.

\section{RESULTS}

Research sample (participants)

CAN was confirmed in 42 patients with median score of $2.8 \pm 0.32$. All subjects were initially randomized in $1: 1$ ratio and split into two groups: group 1 was recommended to continue standard treatment (control group) and group 2 (treatment group) received in addition to standard

Table 1. Clinical characteristic of patients with type 2 diabetes mellitus and confirmed cardiovascular autonomic neuropathy

\begin{tabular}{|c|c|c|}
\hline \multirow{3}{*}{ Parameter } & \multicolumn{2}{|c|}{ Patients with T2DM and confirmed CAN $(n=36)$} \\
\hline & Control (group 1) & Treatment (group 2) \\
\hline & $n=15(100 \%)$ & $n=21(100 \%)$ \\
\hline Age, years & $56[51 ; 59]$ & $55[51 ; 58]$ \\
\hline Males, n (\%) & $7(46.7 \%)$ & $9(42.9 \%)$ \\
\hline Females, n (\%) & $8(57.1 \%)$ & $12(57.1 \%)$ \\
\hline $\mathrm{BMI}, \mathrm{kg} / \mathrm{m}^{2}$ & $26.5[25.8 ; 28.1]$ & $27.2[25.8 ; 28.5]$ \\
\hline Duration of T2DM, years & $4[2 ; 5]$ & $4[2 ; 5]$ \\
\hline \multicolumn{3}{|c|}{ Therapy } \\
\hline Metformin, n (\%) & $6(40 \%)$ & $9(42.9 \%)$ \\
\hline Metformin+sulfonylureas, n (\%) & $9(60 \%)$ & $12(57.1 \%)$ \\
\hline ACE inhibitors / ARB, n (\%) & $11(73.3 \%)$ & $15(71.4 \%)$ \\
\hline$\beta$-adrenergic receptor blockers, n (\%) & $4(26.7 \%)$ & $5(23.8 \%)$ \\
\hline $\mathrm{Ca}^{2+}$ channel blockers, n (\%) & $1(6.7 \%)$ & $2(9.5 \%)$ \\
\hline Aspirin, n (\%) & $13(86.7 \%)$ & $18(85.7 \%)$ \\
\hline
\end{tabular}

Notes: the results are presented as median (Me) and interquartile range (Q25-Q75) and as \%; No statistically significant differences were found. T2DM: type 2 diabetes mellitus; CAN: cardiovascular autonomic neuropathy; BMI: body mass index; ACE inhibitors: angiotensin-converting-enzyme inhibitors; ARB: angiotensin II receptor blockers. 
Table 2. Changes of the fasting blood glucose, $\mathrm{HbA1c}$, and lipid profiles in patients with type 2 diabetes mellitus and confirmed cardiovascular autonomic neuropathy after 3-months of $\omega$-3 polyunsaturated fatty acids therapy

\begin{tabular}{|c|c|c|c|c|c|c|}
\hline \multirow{4}{*}{ Parameter } & \multicolumn{6}{|c|}{ Patients with T2DM and confirmed CAN ( $n=36)$} \\
\hline & \multicolumn{2}{|c|}{ Control (group 1) } & \multicolumn{2}{|c|}{ Treatment (group 2) } & $\begin{array}{c}\text { Control } \\
\text { (group 1) }\end{array}$ & $\begin{array}{l}\text { Treatment } \\
\text { (group 2) }\end{array}$ \\
\hline & \multicolumn{2}{|c|}{$\mathrm{n}=15$} & \multicolumn{2}{|c|}{$\mathrm{n}=21$} & $\mathrm{n}=15$ & $\mathrm{n}=21$ \\
\hline & Baseline & After treatment & Baseline & After treatment & After treatment & After treatment \\
\hline $\mathrm{HbA}_{1 c^{\prime}} \%$ & $7.3[6.5 ; 7.7]$ & $7.3[6.4 ; 7.7]$ & $6.9[6.6 ; 7.5]$ & $7.0[6.4 ; 7.4]$ & $7.3[6.4 ; 7.7]$ & $7.0[6.4 ; 7.4]$ \\
\hline $\begin{array}{l}\text { Fasting glucose, } \\
\mathrm{mmol} / \mathrm{L}\end{array}$ & $7.0[6.1 ; 7.6]$ & $7.0[6.1 ; 7.4]$ & $6.6[6.0 ; 7.6]$ & $6.6[6.0 ; 7.8]$ & $7.0[6.1 ; 7.4]$ & $6.6[6.0 ; 7.8]$ \\
\hline $\mathrm{TC}, \mathrm{mmol} / \mathrm{L}$ & $6.4[5.8 ; 7.3]$ & $6.2[5.7 ; 6.4]$ & $6.1[5.6 ; 6.8]$ & $5.6[4.9 ; 6.4]$ & $6.2[5.7 ; 6.4]$ & $5.6[4.9 ; 6.4] \#$ \\
\hline $\mathrm{TG}, \mathrm{mmol} / \mathrm{L}$ & $2.3[2.2 ; 2.8]$ & $2.1[2.0 ; 2.6]$ & $2.4[2.3 ; 2.6]$ & $1.6[1.4 ; 1.8]^{* * *}$ & $2.1[2.0 ; 2.6]$ & $1.6[1.4 ; 1.8] \# \#$ \\
\hline $\mathrm{HDL}-\mathrm{C}, \mathrm{mmol} / \mathrm{L}$ & $0.83[0.74 ; 0.91]$ & $0.87[0.76 ; 0.92]$ & $0.78[0.7 ; 0.86]$ & $0.83[0.76 ; 0.94]^{* * *}$ & $0.87[0.76 ; 0.92]$ & $0.83[0.74 ; 0.94]$ \\
\hline LDL-C, mmol/L & $4.5[4.1 ; 5.0]$ & $4.4[3.5 ; 4.8]$ & $4.4[3.6 ; 4.8]$ & $3.8[2.9 ; 4.4]$ & $4.4[3.5 ; 4.8]$ & $3.8[2.9 ; 4.4] \#$ \\
\hline
\end{tabular}

Notes: the results are presented as median (Me) and interquartile range (Q25-Q75); $p$ : value: $p<0.001^{* * *}$ compared to baseline; $p<0.05 \#, p<0.01 \# \#$ compared to data of control group, obtained after treatment. T2DM: type 2 diabetes mellitus; $C A N$ : cardiovascular autonomic neuropathy; $\mathrm{HbA}_{1}$ : glycated hemoglobin A1c; TC: total cholesterol; TG: triglycerides; HDL-C: high density lipoprotein-cholesterol; LDL-C: low density lipoprotein cholesterol; ARB: angiotensin II receptor blockers.

Table 3. Changes of the systolic blood pressure parameters during the day in patients with type 2 diabetes mellitus and confirmed stage of cardiovascular autonomic neuropathy after 3-months of $\omega-3$ polyunsaturated fatty acids therapy

\begin{tabular}{|c|c|c|c|c|c|c|}
\hline \multirow{4}{*}{ Parameter } & \multicolumn{6}{|c|}{ Patients with T2DM and confirmed CAN $(n=36)$} \\
\hline & \multicolumn{2}{|c|}{ Control (group 1) } & \multicolumn{2}{|c|}{ Treatment (group 2) } & $\begin{array}{l}\text { Control } \\
\text { (group 1) }\end{array}$ & $\begin{array}{l}\text { Treatment } \\
\text { (group 2) }\end{array}$ \\
\hline & \multicolumn{2}{|c|}{$n=15$} & \multicolumn{2}{|c|}{$n=21$} & $\mathrm{n}=15$ & $\mathrm{n}=21$ \\
\hline & Baseline & After treatment & Baseline & After treatment & After treatment & After treatment \\
\hline SBP, mm Hg & $152[146 ; 158]$ & $150[144 ; 158]$ & $153[148 ; 154]$ & $150[145 ; 152]$ & $150[144 ; 158]$ & $150[145 ; 152]$ \\
\hline $\begin{array}{l}\text { Load of SBP, } \\
\mathrm{mm} \mathrm{Hg} / \mathrm{h}\end{array}$ & $194[148 ; 216]$ & $174[102 ; 202]$ & $156[138 ; 248]$ & $149[132 ; 213]$ & $174[132 ; 202]$ & $149[132 ; 213]$ \\
\hline $\begin{array}{l}\text { Time index } \\
\text { of SBP, \% }\end{array}$ & $74[68 ; 84]$ & $75[60 ; 80]$ & $78[62 ; 82]$ & $72[58 ; 79]$ & $75[60 ; 80]$ & $72[58 ; 79]$ \\
\hline $\begin{array}{l}\text { SD of SBP, } \\
\mathrm{mm} \mathrm{Hg}\end{array}$ & $17[15 ; 19]$ & $16[15 ; 18]$ & $18[14 ; 19]$ & $16[15 ; 19]$ & $16[15 ; 18]$ & $16[15 ; 19]$ \\
\hline
\end{tabular}

Notes: the results are presented as median (Me) and interquartile range (Q25-Q75); No statistically significant differences were found. T2DM: type 2 diabetes mellitus; CAN: cardiovascular autonomic neuropathy; SBP: systolic blood pressure; SD: standard deviation.

treatment 1 capsule/q.d. of $\omega$-3 PUFAs. Six patients were lost to follow-up and the final sample size was 36 patients with T2DM and confirmed CAN comprising 15 patients in control group and 21 subjects in treatment group. Patients were aged between 50-59 yr., with median BMI $27.1 \pm 0.32 \mathrm{~kg} / \mathrm{m}^{2}$ and had disease duration between 1-6 yr. and $\mathrm{HbA}_{1 \mathrm{c}}$ level of $7.1 \pm 0.5 \%$. Metformin was used in $41.7 \%$ of patients and combination of oral hypoglycemic agents (metformin+sulfonylureas) was prescribed to 58.3\%. $86.1 \%$ patients had history of arterial hypertension, among them $83.9 \%$ used angiotensin-converting-enzyme inhibitors or angiotensin II receptor blockers, $29.0 \%$ - $\beta$-adrenergic receptor blockers and $9.7 \%-\mathrm{Ca}^{2+}$-channel blockers. All patients were treated with atorvastatin in daily dose 10 $\mathrm{mg}$, the treatment was stable during six month before the initiation of the study and all treatment period. No differences were found for age, sex distribution, BMI, duration of the disease, hypoglycemic, antihypertensive, lipid-lowering therapy which made them as homogeneous as possible. The hypoglycemic, antihypertensive and lipid lowering therapy was stable during six months before inclusion to the study and remained unchanged during the whole period of investigation.

Clinical characteristic of the patients is presented in table 1.

\section{Primary findings}

We found out that in the control group the baseline levels of $\mathrm{HbA}_{1 \mathrm{c}^{\prime}}$ fasting glucose and lipids profile in blood after three months do not present statistically significant differences. It was established that $\omega$-3 PUFAs do not contribute to statistically significant changes in such parameters as $\mathrm{HbA}_{1 c}$ and glycemia. During the $\omega-3$ PUFAs treatment statistically significant decrease in the levels of TG $(p<0.001)$ and an increase in HDL-C $(p<0.001)$ were observed; no effect on TC and LDL-C content was detected. Compared to the data, obtained in the control group more pronounced decrease in TC $(p<0.05)$, TG $(p<0.01)$ and LDL-C $(p<0.05)$ was found. Changes of the fasting blood glucose, $\mathrm{HbA}_{1 \mathrm{c}^{\prime}}$ and lipid profiles in patients with T2DM and confirmed CAN after 3-months of $\omega$-3 PUFAs therapy are given in table 2. 
Table 4. Changes of the diastolic blood pressure parameters during the day in patients with type 2 diabetes mellitus and confirmed cardiovascular autonomic neuropathy after 3-months of $\omega$-3 polyunsaturated fatty acids therapy

\begin{tabular}{|c|c|c|c|c|c|c|}
\hline \multirow{4}{*}{ Parameter } & \multicolumn{6}{|c|}{ Patients with T2DM and confirmed CAN ( $n=36)$} \\
\hline & \multicolumn{2}{|c|}{ Control (group 1) } & \multicolumn{2}{|c|}{ Treatment (group 2) } & $\begin{array}{c}\text { Control } \\
\text { (group 1) }\end{array}$ & $\begin{array}{l}\text { Treatment } \\
\text { (group 2) }\end{array}$ \\
\hline & \multicolumn{2}{|c|}{$\mathrm{n}=15$} & \multicolumn{2}{|c|}{$\mathrm{n}=21$} & $\mathrm{n}=15$ & $\mathrm{n}=21$ \\
\hline & Baseline & After treatment & Baseline & After treatment & After treatment & After treatmen \\
\hline $\mathrm{DBP}, \mathrm{mm} \mathrm{Hg}$ & $99[96 ; 102]$ & $99[95 ; 100]$ & $95[90 ; 98]$ & $90[85 ; 93]^{* *}$ & $99[95 ; 100]$ & $90[85 ; 93] \# \#$ \\
\hline $\begin{array}{l}\text { Load of DBP, } \\
\mathrm{mm} \mathrm{Hg} / \mathrm{h}\end{array}$ & $134[88 ; 156]$ & $122[80 ; 142]$ & $102[86 ; 134]$ & $86[70 ; 112]^{* * *}$ & $122[80 ; 142]$ & $86[70 ; 112] \#$ \\
\hline $\begin{array}{l}\text { Time index } \\
\text { of DBP, } \%\end{array}$ & $72[60 ; 82]$ & $70[60 ; 79]$ & $75[65 ; 78]$ & $62[56 ; 70]^{* * *}$ & $70[60 ; 79]$ & $62[56 ; 70] \#$ \\
\hline $\begin{array}{l}\text { SD of DBP, } \\
\mathrm{mm} \mathrm{Hg}\end{array}$ & $15[13 ; 16]$ & $13[12 ; 17]$ & $16[15 ; 17]$ & $14[11 ; 15]^{* * *}$ & $13[12 ; 17]$ & $14[11 ; 15]$ \\
\hline
\end{tabular}

Notes: the results are presented as median (Me) and interquartile range (Q25-Q75); $p$ : value: $p<0.01^{* *}, p<0.001^{* * *}$ compared to baseline; $p<0.05 \#, p$ $<0.01$ \#\# compared to data of control group, obtained after treatment.T2DM: type 2 diabetes mellitus; CAN: cardiovascular autonomic neuropathy; DBP: diastolic blood pressure; SD: standard deviation.

Table 5. Changes of the systolic blood pressure parameters during the night in patients with type 2 diabetes mellitus and confirmed cardiovascular autonomic neuropathy after 3-months of $\omega$-3 polyunsaturated fatty acids therapy

\begin{tabular}{|c|c|c|c|c|c|c|}
\hline \multirow{4}{*}{ Parameter } & \multicolumn{6}{|c|}{ Patients with T2DM and confirmed CAN ( $n=36)$} \\
\hline & \multicolumn{2}{|c|}{ Control (group 1) } & \multicolumn{2}{|c|}{ Treatment (group 2) } & $\begin{array}{c}\text { Control } \\
\text { (group 1) }\end{array}$ & $\begin{array}{l}\text { Treatment } \\
\text { (group 2) }\end{array}$ \\
\hline & \multicolumn{2}{|c|}{$\mathrm{n}=15$} & \multicolumn{2}{|c|}{$\mathrm{n}=21$} & $\mathrm{n}=15$ & $n=21$ \\
\hline & Baseline & After treatment & Baseline & After treatment & After treatment & After treatment \\
\hline SBP, $\mathrm{mm} \mathrm{Hg}$ & $138[128 ; 142]$ & $133[125 ; 144]$ & $136[130 ; 150]$ & $132[128 ; 150]$ & $133[125 ; 144]$ & $132[128 ; 150]$ \\
\hline $\begin{array}{l}\text { Load of SBP, } \\
\mathrm{mm} \mathrm{Hg} / \mathrm{h}\end{array}$ & $184[132 ; 196]$ & $174[102 ; 198]$ & $178[112 ; 224]$ & $156[116 ; 202]$ & $174[102 ; 198]$ & $156[116 ; 202]$ \\
\hline $\begin{array}{l}\text { Time index } \\
\text { of SBP, } \%\end{array}$ & $54[42 ; 68]$ & $52[40 ; 60]$ & $56[45 ; 90]$ & $50[41 ; 84]$ & $52[40 ; 60]$ & $50[41 ; 84]$ \\
\hline $\begin{array}{l}\text { SD of SBP, } \\
\mathrm{mm} \mathrm{Hg}\end{array}$ & $15[14 ; 17]$ & $15[13 ; 16]$ & $14[13 ; 18]$ & $14[12 ; 17]$ & $15[13 ; 16]$ & $14[12 ; 17]$ \\
\hline DI, SBP, \% & $-10[-13 ;-8]$ & $-11[-14 ;-8]$ & $-10[-14 ;-2]$ & $-12[-17 ;-1]$ & $-11[-14 ;-8]$ & $-12[-17 ;-1]$ \\
\hline
\end{tabular}

Notes: the results are presented as median (Me) and interquartile range (Q25-Q75); No statistically significant differences were found. T2DM: type 2 diabetes mellitus; CAN: cardiovascular autonomic neuropathy; SBP: systolic blood pressure; SD: standard deviation; DI: diurnal index.

Changes of SBP and DBP parameters during day and night in patients with T2DM and confirmed CAN after 3-months of $\omega$-3 PUFAs therapy are given in tables 3-6.

Prescription of $\omega-3$ PUFAs to patients with T2DM and confirmed CAN was associated with significant decrease of the DBP $(p<0.01)$, load of DBP $(p<0.05)$, time index of DBP $(p<0.05)$ during the day; DBP $(p<0.05)$, load of DBP $(p<0.05)$, time index of DBP $(p<0.05)$, SD DBP $(p<0.01)$ during the night compared to the data, obtained in the control group. Generally treatment was well tolerated, no serious adverse events were fixed. The adverse event, namely mild taste distortion occurred in one patient from treatment group.

\section{DISCUSSION}

Thus, our results enabled us to analyze the effectiveness of the long-chain $\omega-3$ PUFAs on ABPM parameters in patients with T2DM and confirmed CAN. In accordance with International recommendations circadian fluctuations during ABPM are evaluated by the degree of its night-time reduction, the so-called "sleep-time relative BP decline" [14]. Depending on the value of this index 4 types of circadian blood pressure profile are distinguished: "dippers"physiological decrease in BP during the night - sleep-time relative BP decline 10-20\%; "overdippers"- an excessive fall in BP at night, sleep-time relative BP decline $>20 \%$; "nondippers"- the lack of BP reduction at night, sleep-time relative BP decline <10\%; "night-peakers"- night-time BP more than during daily activity, sleep-time relative BP decline $<0$ [14]. The cardiovascular risk and HT prognosis in the vast majority of cases is assessed taking into account only the SBP daily profile [9]. However, DBP is an important predictor of HT outcomes and successful BP control and its daily fluctuations may have clinical and prognostic significance in patients with $\mathrm{HT}$ too. A complete chronobiological analysis of BP using ABPM provides dynamic information about the BP level, which allows optimizing the drugs administration, taking into account the individual BP daily profile [15].

The role of practicable increases in consumption of the long-chain $\omega$-3 PUFAs in HT prevention is promising but 
Table 6. Changes of the diastolic blood pressure parameters during the night in patients with type 2 diabetes mellitus and confirmed cardiovascular autonomic neuropathy after 3-months of $\omega$-3 polyunsaturated fatty acids therapy

\begin{tabular}{|c|c|c|c|c|c|c|}
\hline \multirow{4}{*}{ Parameter } & \multicolumn{6}{|c|}{ Patients with T2DM and confirmed CAN ( $n=36)$} \\
\hline & \multicolumn{2}{|c|}{ Control (group 1) } & \multicolumn{2}{|c|}{ Treatment (group 2) } & \multirow{2}{*}{$\begin{array}{c}\begin{array}{c}\text { Control } \\
\text { (group 1) }\end{array} \\
\mathrm{n}=15\end{array}$} & \multirow{2}{*}{$\begin{array}{c}\text { Treatment } \\
\text { (group 2) }\end{array}$} \\
\hline & \multicolumn{2}{|c|}{$\mathrm{n}=15$} & \multicolumn{2}{|c|}{$\mathrm{n}=21$} & & \\
\hline & Baseline & After treatment & Baseline & After treatment & After treatment & After treatment \\
\hline $\mathrm{DBP}, \mathrm{mm} \mathrm{Hg}$ & $90[86 ; 94]$ & $88[80 ; 92]$ & $89[84 ; 100]$ & $78[71 ; 90]^{* * *}$ & $88[80 ; 92]$ & $78[71 ; 90] \#$ \\
\hline $\begin{array}{l}\text { Load of DBP, } \\
\mathrm{mm} \mathrm{Hg} / \mathrm{h}\end{array}$ & $82[69 ; 88]$ & $76[52 ; 92]$ & $76[56 ; 96]$ & $54[34 ; 76]^{*}$ & $76[52 ; 92]$ & $54[34 ; 76] \#$ \\
\hline $\begin{array}{l}\text { Time index } \\
\text { of DBP, } \%\end{array}$ & $58[49 ; 67]$ & $58[46 ; 66]$ & $62[45 ; 74]$ & $50[40 ; 55]^{* * *}$ & $58[46 ; 66]$ & $50[40 ; 55] \#$ \\
\hline $\begin{array}{l}\text { SD of DBP, } \\
\mathrm{mm} \mathrm{Hg}\end{array}$ & $14[12 ; 16]$ & $13[12 ; 17]$ & $14[11 ; 16]$ & $10[9 ; 13]^{* * *}$ & $13[12 ; 17]$ & $10[9 ; 13] \# \#$ \\
\hline DI, DBP, \% & $-11[-13 ;-8]$ & $-11[-14 ;-7]$ & $-9[-13 ;-1]$ & $-11[-17 ;-0]$ & $-11[-14 ;-7]$ & $-11[-17 ;-0]$ \\
\hline
\end{tabular}

Notes: the results are presented as median (Me) and interquartile range (Q25-Q75); $p$ : value: $p<0.05^{*}, p<0.001^{* * *}$ compared to baseline; $p<0.05 \#$, $\mathrm{p}<0.01$ \#\# compared to data of control group, obtained after treatment. T2DM: type 2 diabetes mellitus; CAN: cardiovascular autonomic neuropathy; DBP: diastolic blood pressure; SD: standard deviation; DI: diurnal index.

understudied. In the current analyses of mid-life adults not taking antihypertensive medications or fish oil supplements, higher serum phospholipid DHA was associated with lower clinic or resting DBP and also with lower 24 hour DBP. Furthermore, a higher serum DHA was associated with lower clinic pulse rate whereas serum EPA was associated only with clinic pulse rate. At the same time, the results of a doubleblind, placebo-controlled clinical trial on patients with T2DM who received either 2 g/q.d. $\omega-3$ soft gel or 2 g/q.d. placebo for 6 wks had no significant effect on SBP and DBP $[16,17]$.

The reasons for arterial stiffness parameters improvement with the use of $\omega-3$ PUFAs can be related to the hypotensive, anti-inflammatory, and antioxidative effects of these fatty acids, as well as to their ability to improve endothelial cell function. Pase et al. (2015) [11] summarized in a systematic review the effect of $\omega-3$ PUFAs supplementation on PWV and other indexes of arterial stiffness. Ten trials met the inclusion criteria with 550 participants randomized to take a dose of $\omega-3$ PUFAs ranging from 0.64 to 3.00 g/q.d. or placebo for a period of 6-105 wks. Studies involved healthy subjects and patients with overweight, DM, HT, and DLP. The treatment with $\omega-3$ PUFAs improved arterial stiffness and the effect was independent of changes in $\mathrm{BP}, \mathrm{HR}$, or BMI. Neither significant heterogeneity nor publication bias was detected. The same author showed recently in a new larger randomized controlled trial on healthy subjects that a high dose of fish oil ( 6 g/q.d.) but not a low dose ( 3 g/q.d.) could reduce aortic pulse pressure and augmentation index, two indirect measures of central BP and arterial stiffness, respectively [11].

Additional evidence of the beneficial effect of $\omega$-3 PUFAs on the vascular structure comes from the inverse association between $\omega$-3 PUFAs intake and the cross-sectional diameter of arteries. It was demonstrated that a larger brachial artery diameter is a significant independent predictor of future cardiovascular events [9]. Accordingly, other authors have reported an inverse association between the brachial artery cross-sectional diameter and the consumption of fish or the concentration of circulatory $\omega-3$ PUFAs. It was demonstrated that the membrane content of $\omega-3$ PUFAs is directly associated with the extent of the vasodilatory response to sublingual nitrate administration, supporting the evidence of a beneficial effect of these fatty acids on the vascular wall [9].

Omega-3 PUFAs decrease level of BP, dose-dependently prevent the development of diabetes, insulin resistance (IR), improve the sensitivity of platelets to ADP and collagen, contribute to positive changes in the parameters of coagulation, endothelial cells migration, enhance and inhibit the proliferation of smooth muscle cells [7].

Others have posited that $\omega-3$ PUFAs may reduce the risk of cardiovascular diseases through antiarrhythmic, antithrombogenic, hypotensive, anti-inflammatory, hypotriacylglycerolaemic, endothelial nitric oxide (NO)stimulating and atherosclerotic plaque growth-inhibiting mechanisms. The findings of this study reveal that the cardioprotective effects of $\omega$-3 PUFAs may also be explained by the ability of $\omega$-3 PUFAs to reduce arterial stiffness [16].

Analysis of experimental and clinical studies proves that $\omega-3$ PUFAs inhibit the absorption of cholesterol in the intestine and its synthesis in the liver, lead to increasing the clearance of lipoproteins in the blood, prevent the development of IR in experimental diabetes, raise levels of glucose transporters GLUT4 mitochondrial RNA skeletal muscles, have a positive effect on the indirect age slowing of blood flow in the brain and improve utilization of glucose in hypertensive rats under stress, there is no influence on the development of hypertension and obesity [7].

The influence of $\omega-3$ PUFAs on the dynamics of metabolism is probably caused by their effects on IR, glucose homeostasis and lipid metabolism (improvement of the lipid profile in patients with T2DM and DLP). In addition, $\omega-3$ PUFAs moderately reduce BP, improve endothelial function, reduce proinflammatory state and improve antioxidant protection [12,7]. Effective influence of $\omega-3$ PUFAs on the dynamics of metabolism is probably due to their effects on IR and glucose homeostasis (IR reduces in the muscle $>$ fat >>liver); inhibition of insulin secretion; lipid metabolism (improves the lipid profile in patients with T2DM and DLP); moderately reduces of BP, improves endothelial function, 
reduces proinflammatory state and improves antioxidant protection $[12,7]$.

We previously reported that the use of $\omega-3$ PUFAs, which contains a one capsule $90 \% \omega-3$ PUFAs, mainly EPA and DHA in treatment of patients with T2DM and CAN improved the general condition of the patients. The evaluation of a vegetative condition (questionnaire Wayne): sum of score was decreased significantly, positive changes of temporal and spectral parameters of HR variability, corrected QT interval was observed; the increasing of the period of inactivity platelet aggregation, inhibition of the first phase aggregation, the decreasing of their hyperactive state, the tendency to normalization of the status of prostacyclin 12thromboxane A2 system was determined [7]. Prescription of $\omega-3$ PUFAs contributed to significant decrease of mean DBP avg., time index of HT DBP, diastolic HT area index and variability of DBP during the day and night hours and was followed by a tendency to a low pulse pressure. The combination of the positive influences of $\omega-3$ PUFAs on content of the $\mathrm{N}$-terminal prohormone of brain natriuretic peptide, certain lipids in the blood, and also noted earlier moderate hypotensive effects of $\omega-3$ PUFAs demonstrates the feasibility of their use in complex treatment of patients with T2DM and CAN $[17,7]$.

Omega-3 PUFAs modulate the parasympathetic and sympathetic interaction through observed changein HR and, in murine models, $\omega-3$ PUFAs increase dopaminergic activity to reduce sympathetic tone. Prior research has implicated impaired baroreflexes in HT both in the young and in the elderly, and $\omega-3$ PUFAs may ameliorate this abnormality. Autonomic modulation of BP is further supported by our observation that pulse rate measured in the seated position, an index of resting autonomic tone, accounting for a substantial portion of the DHA-BP association. Finally, rodents fed diets deficient in $\omega-3$ PUFAs often develop high $\mathrm{BP}$ and do so specifically when consuming relatively large amounts of casein-based protein [18, 7].

Current literature suggests a range of mechanisms through which $\omega-3$ PUFAs may affect $B P$, including but not limited by: a) interacting with the NO pathway and endothelial function, b) lowering vascular tone via blockade of the angiotensin pathway, c) inhibition of thromboxane production and thromboxane-induced vasoconstriction, and d) modulating autonomic tone. Evidence of effects on these pathways tends to be greater for DHA than $\operatorname{EPA}[18,7]$.

The public health importance of $\omega-3$ PUFAs consumption would be substantial if, as opposed to "pharmacologic dosing," normative variability in dietary intake of EPA, DHA, or both were found to affect BP. If that were the case, modest diet modifications might represent a practicable means of preventing or treating $\mathrm{HT}[18,19]$.

We have to acknowledge that the majority of patients studied in the both groups received antihypertensive and all of them received lipid-lowering treatment. However, the use of antihypertensive medications and its regimens were not different between the groups either at the baseline or during the study period without changes within the study period and systolic and diastolic BP did not differ between the groups at the baseline which allow us to suggest that the changes of blood pressure observed in the treatment group were attributed to omega-3 PUFAs and not by actions of antihypertensive medications. The results of our study suggest that prescription of $\omega-3$ PUFAs was associated with decrease in TG and increase of HDL-C levels. It is fair to note the lack of achievement of the lipid-lowering therapy targets, which confirm the necessity of more early and aggressive up- titration of statins.

On the basis of analysis of the results obtained in our study, we concluded that prescription of $\omega-3$ PUFAs contributed to significant decrease of mean DBP, time index, load and variability of DBP pressure. For the latter group, these results are particularly significant, because previously such studies have not been conducted among patients with CAN. The major limitations of our study are small study population and relatively short duration. Further investigations aimed to establish the influence of $\omega$-3 PUFAs on dynamics of independent CARTs, Holter-ECG, ABPM, arterial wall stiffness parameters among patients with T2DM and CAN with longer duration and larger study population are necessary.

\section{CONCLUSIONS}

Prescription of $\omega-3$ PUFAs was associated with improvement of ABPM, namely the decrease of diastolic blood pressure, variability, load and time index of DBP was achieved after 3 months of $\omega-3$ PUFAs administration. The mild antihypertensive effect of proposed treatment was not associated with improved glycemic control, but is rather the result of its action on the vascular wall, hypolipidemic properties, improvement of endothelial function and arterial wall elastic properties. Taking into account the small study population, relatively short study duration and ambiguous data presented in scientific literature, further work with larger sample size and duration aimed to investigate the influence of $\omega-3$ PUFAs on dynamics of independent CARTs, Holter-ECG, ABPM, arterial wall stiffness parameters may provide evidence for hidden therapeutic potential of $\omega-3$ PUFAs and its potential properties for diabetic autonomic neuropathy.

\section{ADDITIONAL INFORMATION}

Financing of work. The work was performed within the frame of the State task of the Danylo Halitsky National Medical University, Lviv, Ukraine.

Conflict of interest. The authors declare no obvious and potential conflicts of interest related to the publication of this article.

Participation of authors. Serhiyenko V.A. - collection of material, statistical data analysis, writing the manuscript text; Mankovsky B.N. management of the research, development of the study design, editing of the manuscript text; Serhiyenko L.M. - management of the research, development of the study design; Serhiyenko A.A. - management of the research, editing of the manuscript text. All authors contributed equally to the review. All authors have read and approve the final version of the manuscript. 


\section{СПИСОК ЛИТЕРАТУРЫ | REFERENCES}

1. Осложнения сахарного диабета: лечение и профилактика. / Под. ред. Дедова И.И., Шестаковой М.В. - М.: Московское информационное агентство; 2017. [Dedov II, Shestakova MV, editors. Complications of diabetes mellitus: treatment and prophylactic. Moscow: Moskovskoe informatsionnoe agentstvo; 2017. (In Russ.)]

2. Vinik Al, Nevoret ML, Casellini C, Parson H. Diabetic neuropathy. Endocrinol Metab Clin North Am. 2013;42(4):747-787. doi: 10.1016/j.ecl.2013.06.001

3. Balcioglu AS, Muderrisoglu H. Diabetes and cardiac autonomic neuropathy: Clinical manifestations, cardiovascular consequences, diagnosis and treatment. World J Diabetes. 2015;6(1):80-91. doi: 10.4239/wjd.v6.i1.80

4. Ziegler D, Keller J, Maier C, et al. Diabetic neuropathy. Exp Clin Endocrinol Diabetes. 2014;122(7):406-415. doi: 10.1055/s-0034-1366435

5. Pop-Busui R, Boulton AJ, Feldman EL, et al. Diabetic Neuropathy: A Position Statement by the American Diabetes Association. Diabetes Care. 2017:40(1):136-154. doi: 10.2337/dc16-2042

6. Spallone V, Ziegler D, Freeman R, et al. Cardiovascular autonomic neuropathy in diabetes: clinical impact, assessment, diagnosis, and management. Diabetes Metab Res Rev. 2011;27(7):639-653. doi: 10.1002/dmrr.1239

7. Serhiyenko VA, Serhiyenko LM, Serhiyenko AA. Omega-3 polyunsaturated fatty acids in the treatment of diabetic cardiovascular autonomic neuropathy: A review. In: Moore SJ, editor. Omega-3: Dietary sources, biochemistry and impact on human health. New York: Nova Science Publishers; 2017

8. Townsend RR, Wilkinson IB, Schiffrin EL, et al. Recommendations for Improving and Standardizing Vascular Research on Arterial Stiffness: A Scientific Statement From the American Heart Association. Hypertension. 2015;66(3):698-722. doi: 10.1161/HYP.0000000000000033

9. Colussi G, Catena C, Novello M, et al. Impact of omega-3 polyunsaturated fatty acids on vascular function and blood pressure: Relevance for cardiovascular outcomes. Nutr Metab Cardiovasc Dis. 2017:27(3):191-200. doi: 10.1016/j.numecd.2016.07.011
10. Koumaras C, Katsiki N, Athyros VG, Karagiannis A Metabolic syndrome and arterial stiffness: the past, the present and the future. J Cardiovasc Med (Hagerstown). 2013;14(10):687-689. doi: 10.2459/JCM.0b013e3283657c96

11. Pase MP, Grima N, Cockerell R, et al. The effects of long-chain omega-3 fish oils and multivitamins on cognitive and cardiovascular function: a randomized, controlled clinical trial. J Am Coll Nutr. 2015;34(1):21-31. doi: 10.1080/07315724.2014.880660

12. Harris WS, Del Gobbo L, Tintle NL. The Omega-3 Index and relative risk for coronary heart disease mortality: Estimation from 10 cohort studies. Atherosclerosis. 2017;262:51-54. doi: 10.1016/j.atherosclerosis.2017.05.007

13. Arteriograph.nl [Internet]. Arteriograph and TensioMed ${ }^{\mathrm{TM}}$ program Available from: http://www.arteriograph.nl/.

14. Hermida R, Smolensky MH, Ayala DE, et al. 2013 ambulatory blood pressure monitoring recommendations for the diagnosis of adult hypertension, assessment of cardiovascular and other hypertension-associated risk, and attainment of therapeutic goals. Chronobiol Int. 2013;30(3):355-410. doi: 10.3109/07420528.2013.750490

15. Mahabala C, Kamath P, Bhaskaran U, et al. Antihypertensive therapy: nocturnal dippers and nondippers. Do we treat them differently? Vasc Health Risk Manag. 2013:9:125-133. doi: 10.2147NHRM.S33515

16. Kiecolt-Glaser JK, Epel ES, Belury MA, et al. Omega-3 fatty acids, oxidative stress, and leukocyte telomere length: A randomized controlled trial. Brain Behav Immun. 2013;28:16-24. doi: 10.1016/j.bbi.2012.09.004

17. Mansour AS, Yannoutsos A, Majahalme N, et al. Aortic stiffness and cardiovascular risk in type 2 diabetes. $J$ Hypertens. 2013;31(8):1584-1592. doi: 10.1097/HJH.0b013e3283613074

18. Campbell F, Dickinson HO, Critchley JA, et al. A systematic review of fish-oil supplements for the prevention and treatment of hypertension. Eur J Prev Cardiol. 2013;20(1):107-120. doi: 10.1177/2047487312437056

19. Serhiyenko VA, Serhiyenko AA. Cardiac autonomic neuropathy: Risk factors, diagnosis and treatment. World J Diabetes. 2018;9(1):1-24. doi: 10.4239/wjd.v9.i1.1

\section{ИНФОРМАЦИЯ ОБ АВТОРАХ [AUTHORS INFO]}

*Сергиенко Виктория Александровна, д.м.н., доцент [Victoria A. Serhiyenko, MD, PhD]; адрес: Украина, 79010, Львов, ул. Пекарская, д. 69 [address: 69, Pekarska street, Lviv, 79010 Ukraine]; ORCID: http://orcid.org/0000-0002-6414-0956; e-mail: serhiyenkov@gmail.com

Маньковский Борис Никитич, д.м.н., профессор, член-корреспондент HAMH Украины [Boris N. Mankovsky, MD, PhD, Professor]; адрес: Украина, 04112, Киев, ул. Дорогожицька, д. 9 [address: 9, Dorohozhytska street, Kyiv, 04112, Ukraine]; ORCID: http://orcid.org/0000-0001-8289-3604; e-mail: mankovsky1964@yahoo.com

Сергиенко Людмила Михайловна, к.б.н., доцент [Ludmila M. Serhiyenko, MD, PhD]; адрес: Украина, 79010, Львов, ул. Пекарская, д. 69 [address: 69, Pekarska street, Lviv, 79010 Ukraine]; ORCID: http://orcid.org/0000-0001-9873-9847; e-mail: serhiyenkoludmila@gmail.com

Сергиенко Александр Алексеевич, д.М.Н., профессор [Aleksandr A. Serhiyenko, MD, PhD, Professor]; адрес: Украина, 79010, Львов, ул. Пекарская, д. 69 [address: 69, Pekarska street, Lviv, 79010 Ukraine]; ORCID: http://orcid.org/0000-0002-3905-0326; e-mail: serhiyenkoa@gmail.com

\section{ЦИТИРОВАТЬ:}

Сергиенко В.А., Маньковский Б.Н., Сергиенко Л.М., Сергиенко А.А. Влияние омега-3 полиненасыщенных жирных кислот на параметры амбулаторного мониторинга артериального давления у больных сахарным диабетом 2 типа и автономной невропатией сердца // Сахарный диабет. - 2019. — T. 22. — №1. — C. 62-69. doi: 10.14341/DM9630

\section{TO CITE THIS ARTICLE:}

Serhiyenko VA, Mankovsky BN, Serhiyenko LM, Serhiyenko AA. The effect of OMEGA-3 polyunsaturated fatty acids on ambulatory blood pressure monitoring parameters in patients with type 2 diabetes mellitus and cardiovascular autonomic neuropathy. Diabetes Mellitus. 2019;22(1):62-69. doi: 10.14341/DM9630 